\title{
Frank S Bloch (ed): The Global Clinical Movement: Educating Lawyers for Social Justice
}

Oxford University Press, 2011, 400 pp, ISBN: 978-0-19-538114-6 (HB)

\author{
Meher Dev ${ }^{1}$
}

Accepted: 22 December 2020 / Published online: 28 January 2021

(c) O.P. Jindal Global University (JGU) 2021

The Global Clinical Movement is a book edited by Frank S Bloch, Professor of Law and Director of Clinical Education at Vanderbilt University's School of Law. This book is a significant contribution towards understanding how clinical legal education and its justice mission culminated in a global movement. It is a remarkable collaboration of scholarship and thought leadership by clinical legal educators from all over the world. Most of the contributors of this book are members of the Global Alliance for Justice Education (GAJE), an ever-expanding global alliance of law teachers committed to achieving social justice through education. In the preface to the book, Bloch noted that the idea of such a global alliance was first floated at a course for Indian clinical teachers organised by Dr NR Madhava Menon.

Published in 2011, this book made a strong case for taking the global relevance of clinical legal education seriously by focusing on three aspects of such education: its global reach (Part I), its social justice mission (Part II), and its emergence as a worldwide movement (Part III). It helped set the stage for a global clinical movement and for this movement to take forward the project of justice education within a global context. It provided insights into core aspects of clinical legal education. It proposed a vision and an agenda, and suggested concrete recommendations and strategies to strengthen the global clinical movement that was already under way.

Almost a decade has passed since the publication of this book. Some later works have spoken about, described, and to some extent taken stock of the developing aspects of the global clinical movement. ${ }^{1}$ However, recent scholarship is lacking on

\footnotetext{
1 See, e.g., Richard J Wilson, The Global Evolution of Clinical Legal Education: More Than a Method (Cambridge University Press 2017); Shuvro Sarker (ed), Clinical Legal Education in Asia: Accessing Justice for the Underprivileged (Palgrave Macmillan 2015); A Alemanno and L Khadar (eds), Reinventing Legal Education: How Clinical Education Is Reforming the Teaching and Practice of Law in Europe (Cambridge University Press 2018).
}

Meher Dev

md3592@columbia.edu

1 Cornell Law School, Ithaca, NY, USA 
the point of shaping the future of the global clinical movement in a manner that is informed by contemporary needs and takes into account the impact of the COVID19 pandemic on clinical programmes. Today, it is imperative for us to methodologically take stock of developments in the global clinical movement. It is necessary to engage in a forward-looking exercise to address the contemporary needs of the movement. This exercise is crucial for us to effectively chart next steps and shape the future of the global clinical movement. This exercise must include analysing the implementation of the proposed agenda and recommendations made in 2011 in the book, identifying and analysing contemporary issues facing the global clinical movement today, and designing innovative collaborative solutions to continue moving the global clinical movement forward.

Acknowledging the need for combined efforts and thought leadership required to successfully undertake this meticulous exercise, in this book review, I provide fellow scholars and clinical legal educators a head start into the renewed project in front of us. I begin undertaking this exercise by linking select recommendations and insights provided by the contributors of the book to today's realities. I highlight select contemporary issues and identify areas for further scholarship and inquiry that can help strengthen today's global clinical movement. After undertaking this preliminary mapping, I pose questions on how the pandemic might affect the work of clinics and the opportunities it may present for clinicians, students, the legal profession, and communities to engage in problem solving to continue their social justice work. I conclude by recommending that such an inquiry be completed and take the form of a revised book edition of The Global Clinical Movement that charts steps for the next decade.

\section{The global reach of clinical legal education}

In Part I of the book, 'The Global Reach of Clinical Legal Education', clinical legal educators and scholars provided valuable insights into the modern roots of clinical legal education. They inquired into the introduction and running of clinical programmes in the four first-wave countries, and in Africa, Australia, Central and Eastern Europe, Latin America, and South and Southeast Asia. These insights remain relevant today. The book continues to help build the case for institutionalising clinical education in other parts of the world where such education is in its nascent stages and lacks full institutional support.

However, today it is crucial to highlight the challenges to the clinical movement that were discussed in this book in 2011 and that continue to exist today. These challenges require targeted response to help the movement grow to its fullest potential. Clinical legal education in countries covered by this book, by the mere passage of time from the publication of this book, has undergone developments. There is a need to review and map the status of earlier identified challenges and analyse new developments in clinical legal education. It is important to identify shared lessons and areas of collaboration to overcome contemporary challenges and amplify successes to keep the global clinical movement growing. 
Below, I summarise developments in clinical legal education in countries discussed by the contributors of the book. Then, I identify select contemporary developments in clinical legal education and provide a preliminary mapping of developments documented in the book with these contemporary developments. I make a case for new scholarship and inquiry into select contemporary topics of clinical legal education that can fuel the growth of the clinical movement locally and globally.

\subsection{Four first-wave countries}

Jeff Giddings, Roger Burridge, Shelley Gavigan, and Catherine Klein provided insights on Britain, Canada, Australia, and the US as the four first-wave countries. They noted a slow development of the clinical movement in Britain. Legal education being divided into an academic stage followed by a professional stage was seen to contribute to this slow development. The year-long training requirement before seeking admission to the bar was noted as another slowing-down factor. However, today, in 2020, over 200 live-client clinics have been seen to be running in Britain with university-led clinics being a popular model. ${ }^{2}$ Over the past years, scholarship has been produced analysing regulatory restrictions imposed on university law clinics. These restrictions pertain to insurance, reserved legal activities, and limits on specific areas of advice that can be given at university law clinics. ${ }^{3}$ Recommendations have been made on how clinicians can secure a more enabling future. ${ }^{4}$ There might be lessons for other countries to be learnt on how to sustain and grow in restrictive regulatory environments through existing scholarship and strategies being produced in Britain. ${ }^{5}$

In relation to Canada, contributors noted opposition from the legal profession as an obstacle to the growth of legal clinics. In 2020, a supervising lawyer at a clinic there noted that some members of the legal community had softened towards clinics while some perceived clinic work as 'simple law' that self-representatives could do. ${ }^{6}$ So at least anecdotally, the opposition from the legal profession seems to have softened. Other challenges facing clinics in Canada today relate to funding, pay disparities in salaries of clinicians and professors, mindset at some law faculties of seeing clinics as 'add-ons' and 'co-curricular', and restrictions on law students with regard to representing clients facing summary conviction criminal charges. ${ }^{7}$ These challenges are not unique to Canada, and other countries discussed in this book seem to be grappling with similar challenges. There is an opportunity for collaboration between clinicians from these countries in a possible next edition of the book.

\footnotetext{
${ }^{2}$ Lydia Bleasdale et al., 'Law Clinics: What, Why and How?' in Linden Thomas and Nick Johnson (eds), The Clinical Legal Education Handbook (University of London Press 2020) 7, 9.

3 See Linden Thomas, 'Law Clinics in England and Wales: A Regulatory Black Hole' (2017) 51(4) The Law Teacher 469; Linden Thomas, 'Regulatory Framework' in Thomas and Johnson, The Clinical Legal Education Handbook (n 2) 57-239.

4 Ibid.

5 Ibid.

6 Sarah Buhler et al., 'Clinical Legal Education on the Ground: A Conversation' (2020) 32 Journal of Law and Social Policy 127, 134.

7 Ibid. 136; Martha Simmons et al., 'ACCLE Past, Present, and Future: Reflections from ACCLE's Board Presidents' (2020) 32 Journal of Law and Social Policy 111, 120, 121.
} 
Contributors noted that Australia's focus on vocational programmes and simulated programmes hindered the growth of clinical methods in law school teaching. In 2017, other scholars noted that there was wider recognition that experiential learning should take place within the law school through clinics rather than being limited to vocational programmes. ${ }^{8}$ Clinics were seen to have the advantage of strengthening the academic phase of legal education and helping students in building skills to address the legal, emotional, and systemic needs of real clients. ${ }^{9}$ Scholars also noted ongoing debates on the issue of whether simulated programmes could be included under the umbrella of clinical legal education. ${ }^{10}$ In any case, they saw it as a valuable tool to prepare students to serve real clients. ${ }^{11}$ They recommended taking an integrative approach to clinical legal education and using both simulations and realclient experiences to help prepare students for law practice. ${ }^{12}$

Contributors saw the clinical movement in the US to be growing at an optimistic pace, noting the spread of institutionally recognised credit-based clinics. However, they also noted the treatment of clinical teaching methods as secondary to the doctrinal methods of teaching. At the time, clinic faculty was not being considered on a par with other doctrinal faculty and not being paid commensurately. Many of these issues disappointingly have remained true over the past years, as clinic faculty have had to fight for tenure status. ${ }^{13}$ While some clinic faculty members in the US have managed to secure tenured positions, there has been another new growing concern about the culture of clinics of hiring short-term teaching fellows. ${ }^{14}$ Clinical fellowship programmes can really help provide training to those wanting to become clinical law teachers. However, lower-cost staffing of clinic fellows without mentorship and due attention to their future hiring and career advancement can be exploitative. ${ }^{15}$

Later scholarship has noted the recent claim of some that clinics in the US tend to increase law school tuition fees. ${ }^{16}$ Such claims can deter law schools from supporting and establishing clinics. These claims have been credibly refuted through

\footnotetext{
8 Adrian Evans et al., 'Australian Clinical Legal Education: Models and Definitions' in Australian Clinical Legal Education: Designing and Operating a Best Practice Clinical Program in an Australian Law School (ANU Press 2016) 39, 40, 43.

9 Ibid. 43.

10 Ibid. 44.

11 Ibid.

12 Ibid. 45.

13 BL Adamson et al., 'The Status of Clinical Faculty in the Legal Academy: Report of the Task Force on the Status of Clinicians and the Legal Academy' (2012) 36(2) Journal of the Legal Profession 353, 413, 414; Elizabeth A Keyes et al., 'Clinical Legal Education: A (Brief) Comparison of the Evolving Structures and Pedagogy in Mexico, Canada and the United States' (2014) 91 University of Detroit Mercy Law Review 1, 4, 5.

14 Keyes et al., 'Clinical Legal Education' (n 13) 4; Adamson et al., 'The Status of Clinical Faculty in the Legal Academy' (n 13) 413, 414.

15 Adamson et al., 'The Status of Clinical Faculty in the Legal Academy' (n 13) 413, 414; Keyes et al., 'Clinical Legal Education' (n 13) 4.

16 Robert R Kuehn, 'Pricing Clinical Legal Education' (2014) 92 Denver University Law Review 1, 5.
} 
data-based studies in the US. ${ }^{17}$ About five years ago, an 'experiential training requirement' for six credits was adopted. ${ }^{18}$ Clinical legal educators have welcomed this move and one may still opine that the clinical movement is growing at an optimistic pace in the US. But a noteworthy clinician in the US has aptly identified a need for more growth. In an interview published in 2020, he opined that there is still more 'need for students to spend a greater portion of their professional training not just learning to think like a lawyer but learning how to do like a lawyer'. ${ }^{19}$

\subsection{Africa}

David McQuoid-Mason, Ernest Ojukwu, and George Mukundi Wachira showcased university legal aid clinics in Africa as promising models to support the work of national legal aid bodies in developing countries. Today, Nigeria is seen as a 'rising star' with its clinical legal curriculum applied in more than 15 university-based law clinics. ${ }^{20}$ Most law schools in South Africa have law clinics operating under the South African University Law Clinics Association. ${ }^{21}$ However, university law clinics have been facing challenges of low funding and low academic recognition of clinic staff. ${ }^{22}$

In 2020, scholars noted that while law clinics have been blooming in countries in Africa, 'the information available about them is sketchy at best and not as systematic as it is about South Africa or, in last few years, Nigeria.' ${ }^{23}$ Scholars have made recommendations as to how clinical legal education can be used in Kenya to promote a public service ethic in the legal profession. ${ }^{24}$ There is a need for a systematic inquiry into the development of clinical legal education in African countries other than Nigeria and South Africa. This will help identify how the global clinical movement and clinics in Nigeria and South Africa can support local clinics in other African countries.

\footnotetext{
17 Ibid.

18 Robert Kuehn, 'Surveying Clinical Education, A Conversation with Robert Kuehn' (2020) 6(2) Clinical Legal Education. See 'The Standardization of Law School Clinics: How Law School Accreditation Standards Help Shape Clinical Legal Education' (2020) 6(2) Clinical Legal Education. https://thepractic e.law.harvard.edu/issue/volume-6-issue-2/. Accessed 20 December 2020.

19 Kuehn, 'Surveying Clinical Education' (n 18).

${ }^{20}$ Lynette Osiemo and Anton Kok, 'Promoting a Public Service Ethic in the Legal Profession in Kenya: The Imperative Role of Clinical Legal Education' (2020) 64(2) Journal of African Law 173, 184. See Richard J Wilson, 'African Clinics Today: Nigeria Leads the Way in Clinical Legal Education in Africa' in The Global Evolution of Clinical Legal Education (n 1) 215-219.

21 Osiemo and Kok, 'Promoting a Public Service Ethic in the Legal Profession in Kenya' (n 20) 184.

22 Donald Nicholson, 'Our Roots Began in (South) Africa: Modeling Law Clinics to Maximize Social Justice Ends' (2016) 23(3) International Journal of Clinical Legal Education 87, 89, 134.

23 Osiemo and Kok, 'Promoting a Public Service Ethic in the Legal Profession in Kenya' (n 20) 185.

24 Ibid.
} 


\subsection{South and Southeast Asia}

Bruce A Lasky and MRK Prasad provided insights into the clinical movement in South and Southeast Asia. At the time, the movement there was relatively young and far from bringing fully accredited clinical programmes, with the exception of India. They closely studied India's legal aid movement and welcomed the incorporation of mandatory clinical legal education in law schools there. They saw India as a positive example for the Asian region. At the same time, they recognised challenges and successes in truly bringing to life the social justice mission of clinics in India.

These challenges, unfortunately many of which remain true today, included the general ban on students and full-time professors from practising law; ${ }^{25}$ legal aid clinics being established as consultation clinics and not credit-based clinics; ${ }^{26}$ clinical programmes lacking client interaction; and limited participation of students in competitive experience-building moot courts. While courses on drafting, pleading, conveyance, and professional ethics were taught by practising lawyers or those with some practice experience, they were confined to classroom teaching and evaluation. Contributors called for more oversight by the Bar Council of India with targeted guidance on implementation of clinical courses. Over the past years, scholars have noted lack of funding especially in public law schools, meagre salaries for adjunct faculty that are practising law, and lack of full-time faculty with prior practice experience as barriers to clinical legal education in India. ${ }^{27}$

A success noted by the contributors was the opportunity for Indian clinics to engage in public interest litigation before the Supreme Court and High Courts in India. They noted that clinics could undertake a full range of legal tasks including appearing before courts, thereby helping students to develop litigation and advocacy skills. Another success noted was that of some law schools providing academic incentive to students to participate in people's courts - lok adalats. While public interest litigation and lok adalats are promising avenues for law clinics to engage in social justice education, there is dearth of data on how these avenues are being used by clinics. There is a need to fill this gap in data by undertaking a methodological study on this issue and encouraging the use of these avenues for clinical legal education.

In relation to Southeast Asia, contributors recommended that credited live-service clinical teaching should complement the prevalent lecture-oriented and noncredited simulated teaching. Even today, the movement in South and Southeast Asia is struggling to integrate clinics into the curriculum and bring full accreditation to

\footnotetext{
${ }_{25}$ Sital Kalantry, 'Promoting Clinical Legal Education and Democracy in India' (2015) 8(1) NUJS Law Review 1, 5 .

26 Ibid.

27 Frank S Bloch, review of Clinical Legal Education in Asia (2016) 3(2) Asian Journal of Legal Education 216, 217; C Raj Kumar, 'Legal Education, Globalization, and Institutional Excellence: Challenges for the Rule of Law and Access to Justice in India' (2013) 20(1) Indiana Journal of Global Legal Studies $1,221,249$.
} 
clinics with a few exceptions. ${ }^{28}$ For example, Jindal Global Law School in India ran its first fully accredited Good Rural Governance Clinic course in 2012 in collaboration with Cornell Law School's International Human Rights Clinic. ${ }^{29}$ However, offering credit-based clinical courses is not the norm yet in South and Southeast Asia and fully accredited clinical programmes still remain the exception.

\subsection{Central and Eastern Europe}

Mariana Berbec-Rostas, Arkady Gutnikov, and Barbara Namyslowska-Gabrysiak noted that the education reform movement in Europe began in the 1990s with the motive of filling in the gap of practice-oriented value-based teaching. This motive was driven by the need to form a 'critical mass' of future judges and lawyers who share similar values of rule of law, human rights, and social justice. This critical mass would then help in the substantive implementation of rule of law reforms beyond their formalistic adoption. Clinical legal education was seen as a means to build the required critical mass.

Contributors noted that up to the early 2000s, the main focus of the education reform in European countries was on a higher education restructuring initiative in select European countries, called the Bologna Process. This process focused on enabling transferability of knowledge and skills across European countries. Contributors identified this as an opportunity to incorporate clinical legal education as part of the Bologna Process. They noted that given the unique historical and geo-political developments in Central and Eastern Europe, clinical legal education and its development needed to be analysed country by country. But in most countries discussed by the contributors, clinics started as pilot initiatives and grew with the support of the legal academy and foreign donors.

In relation to Poland, contributors noted that the clinic movement was beyond the organising phase with most law schools having clinics and being in the process of developing clinics into an essential component of the legal curriculum. In relation to Russia, the contributors noted that by 2009 , there were more than 150 legal clinics with a broad mission of legal aid and human rights, but for the most part legal clinics were an optional course. In relation to Ukraine, they noted that clinics were credit-based like other optional courses. In relation to Western Balkans, they noted that most law schools with a few exceptions did not have clinical programmes. These exceptions included clinics in Bosnia and Herzegovina and Croatia. In relation to Bulgaria, they noted that a stride forward was made in 2005 when existing clinical programmes signed the Academic Standards for the Organization and Activities of Legal Clinics in a move to unify the model of clinical education. However, clinics

\footnotetext{
${ }^{28}$ Kalantry, 'Promoting Clinical Legal Education and Democracy in India' (n 25) 12; Bloch, 'Clinical Legal Education in Asia' (n 27) 217.

29 Kalantry, 'Promoting Clinical Legal Education and Democracy in India' (n 25) 9-11. See generally, Priya Gupta et al., 'How Clinical Education Builds Bridges with Villages for a Global Law School in India' (2014) 63(3) Journal of Legal Education 512.
} 
are not mandatory. Similar was the case in Hungary, where clinics were noted to be optional but credit-based and led by full-time professors.

Over the past few years, scholars have noted the uneven development of clinics in Central and Eastern Europe with Poland still being seen as the 'gold standard' 30 This unevenness has been attributed to differences in funding including loss of foreign funding, clinic staffing, and legislative barriers to fully integrating clinics into the law school curriculum. ${ }^{31}$ This uneven development requires closer scrutiny, and clinicians from the region who have been able to overcome these barriers may be well positioned to support their peers in the region to address these challenges.

\subsection{Western Europe and the Middle East}

While Diego Blázquez-Martín explored in detail the opportunity that the Bologna Process provided Spain to reform its legal education using clinical legal education, the development of clinics in other Western European countries was not explored in the book. In the introduction to the book, Bloch made a special mention of the existence and potential of clinical programmes in Western Europe and the Middle East. He noted that the book did not cover these regions.

Over the past few years, scholars have noted the difference in approach to clinics in Central and Eastern Europe and Western Europe, the former being more enthusiastic and the latter being more resistant to adopting clinical legal education methods. ${ }^{32}$ Especially, the last few years have seen emerging scholarship on clinical legal education in Western Europe and the Middle East. ${ }^{33}$ For instance, the University of Brescia's Law Clinic in Italy was cited by a scholar as a promising example of how European clinics can build association with local bars and collaborate with practitioners who can supervise students. ${ }^{34}$ Germany has seen a blooming of refugee law clinics. ${ }^{35}$ Scholars have called for establishing specialised environmental clinics in

\footnotetext{
${ }^{30}$ Dubravka Aksamovic and Philip Genty, 'An Examination of the Challenges, Successes and Setbacks for Clinical Legal Education in Eastern Europe' (2014) 20(1) International Journal of Clinical Legal Education 427, 433-434. See Katarzyna Ważyńska-Finck, 'Poland as the Success Story of Clinical Legal Education in Central and Eastern Europe: Achievements, Setbacks, and Ongoing Challenges' in Alemanno and Khadar, Reinventing Legal Education (n 1) 44-56.

31 Ibid.

32 Aksamovic and Genty, 'An Examination of the Challenges, Successes and Setbacks' (n 30) 428-429.

33 See Richard J Wilson, 'Clinical Legal Education in the Middle East' and 'Clinical Legal Education in Continental Western Europe' in The Global Evolution of Clinical Legal Education (n 1) 287-300, 301-331; Maryam Torabi and Seyed Masoud Noori, 'The Necessity of Transitioning from Generic Legal Clinics to Specialized Environmental Law Clinics in MENA Region with Focus on Iran' (2018) 5(1) Asian Journal of Legal Education 169; Alemanno and Khadar, Reinventing Legal Education (n 1).

${ }^{34}$ Laura Bugatti, 'Legal Education in the Next Future' (2019) 26(3) International Journal of Clinical Legal Education 3, 23. See Marzia Barbera, 'The Emergence of an Italian Clinical Legal Education Movement: The University of Brescia Law Clinic' in Alemanno and Khadar, Reinventing Legal Education (n 1) 59-75.

35 Jan-Gero Alexander Hannemann and Georg Dietlein, 'The Development of Refugee Law Clinics in Germany in View of the Refugee Crisis in Europe' (2018) 25(2) International Journal of Clinical Legal Education 160, 163.
} 
Iran. ${ }^{36}$ It might be useful to delve deeper, build more scholarship, and identify areas for collaboration to support the emergence and growth of clinical legal education in Western Europe and the Middle East.

\subsection{Latin America}

Erika Castro-Buitrago, Nicolás Espejo-Yaksic, Mariela Puga, and Marta Villarreal provided insights into the history of clinics in Latin America that were supported through seed funding from the US. They demonstrated the scope and growth of clinical legal education through Public Interest Law Clinics in Latin America. They identified questions and potential issues in the growth of the movement there. These included lack of a consolidated regional clinical movement, isolation of clinics from the law school curriculum, lack of long-term sustainable strategies to keep the clinic running, and progressive budget restrictions.

In relation to Argentina, contributors noted that the government agency in charge of law school accreditation in the 2000s started to show greater concern for practical legal training and social impact. That provided momentum to clinical education and led to the expansion of practice-oriented courses. Two models of clinical teaching were being debated. In the first model, only skills without connection to social justice content were being taught. In the second model, teaching of skills and training in social justice were being delegated to NGOs. The first model was being resisted by public universities as a North American model not suitable for the goals of social justice and for connecting legal education with public affairs. The second model was being seen as placing practical training at NGOs rather than in the academy.

In Chile, contributors noted that innovative clinics were developed under the guidance of the Latin American Network of Public Interest Law (PIL) Clinics from the 1990s to 2007. They noted that although the PIL network ceased to exist, these PIL clinics continued using and developing new forms of PIL litigation to connect legal practice with social justice. They advocated before national courts and the Inter-American Commission and Inter-American Court of Human Rights on social issues including rights of women, indigenous peoples, sexual minorities, people living with HIV, and detainees. By 2009, most law schools provided some form of clinical education. However, clinics had not yet become a fundamental part of the process of legal education reform.

In Colombia, contributors noted the positive evolution of clinics and their leading work on rights of women, children, and persons with disabilities. However, clinics had been marginalised in the curriculum, lacked full-time professor supervision, and lacked adequate budgets. Some universities in Bogotá had institutional support. In Mexico, contributors noted that some clinics were facing backlash for their work from law schools that were trying to maintain the status quo. For example, a PIL clinic that was offered as an optional course was closed down after the clinic's involvement in some public interest cases that were challenging societal inequalities.

36 Torabi and Noori, 'The Necessity of Transitioning from Generic Legal Clinics' (n 33). 
Contributors noted the push provided for incorporation of clinics by the constitutional reform of 2008. This reform provided for a shift from inquisitorial to adversarial trials that would require students to be trained for oral advocacy. But still, at the time, clinical education remained limited in its reach.

While there has been some recent examination of the clinical education movement in Latin America, scholarship seems limited in terms of its recency and accessibility. ${ }^{37}$ There is need for scholars to produce scholarship on how the movement has grown there.

\subsection{China}

In China, clinical teachers and members of the Committee of Chinese Clinical Legal Educators (CCLE) acted as pioneers in the spread of clinical legal education. Contributors to the book Cai Yanmin and JL Pottenger Jr noted that by 2009, over 70 institutions had formally integrated clinical education to some extent in their law school curricula. Chinese leadership was supported through collaborations with clinicians from the US. There were US-funded public interest fellowship programmes for law graduates and trainings for clinicians. Specialised clinics including mediation clinics, labour rights clinics, legislation clinics, litigation, and public interest clinics were established and drew inspiration from US-style law school clinics.

Contributors highlighted that in the course of modernisation, China could not afford to neglect social groups that had been excluded from the country's economic growth. Social justice lawyers played a key role in advocating for these groups and clinics were a means to train social justice lawyers. Clinical education was seen as having positively become an integral part of China's legal education within the first decade of the clinical movement in China (1999-2009). However, contributors identified certain challenges that may not have been unique to clinics in China but required a Chinese solution to meet the contextual requirements of the legal and academic culture there. This perspective was seen to help make clinics in China less of an 'American transplant'.

These challenges included lack of a 'student practice rule' especially in criminal cases where anecdotal evidence demonstrated that clinic students could meet their client only on the day of trial, lack of a strong and well-developed public interest segment of the Chinese bar, the status of clinics still being 'optional', confusion between 'clinical' work and 'practical training', teachers and students not being commensurately rewarded for their clinic work, linking professional growth and rewards in the clinic teaching profession to doctrinal scholarship, and heavy reliance on US-sourced funding with little funds from within China.

In 2011, the Ministry of Education and the Central Political and Legal Committee in China required law schools to offer practical legal skills courses and required

\footnotetext{
37 See generally Richard J Wilson, 'Clinical Legal Education in Latin America' in The Global Evolution of Clinical Legal Education (n 1) 153-179; Fernando Munoz L, 'Cause Lawyering and Compassionate Lawyering in Clinical Legal Education: The Case of Chile' (2020) 27(1) Indiana Journal of Global Legal Studies 231.
} 
that such courses make up no less than 15 per cent of the curriculum. While this has been a positive step, scholars over the past years have identified several problems associated with such practical legal skills courses. ${ }^{38}$ These problems include lack of funding, heavy research duties of teachers, teachers lacking practical legal experience to be able teach these courses, lack of stable institutional arrangements with practising lawyers to serve as teachers for these courses, and lack of locus standi for clinic students in criminal matters. ${ }^{39}$ It is concerning that over the past years, a new list of challenges has been identified in China. An organised inquiry is required into how the global clinical movement can help clinicians in China address these challenges.

\subsection{Japan}

Shigeo Miyagawa, Takao Suami, Peter A Joy, and Charles D Weisselberg provided insights into the development of clinics in Japan. They noted that in 2001, the Japanese Justice System Reform Council issued broad recommendations that expected law schools to develop education frameworks that bridged the gaps between theory and practice. Accreditation standards required clinical courses. Thus, in 2004, new law schools were opened with the aim of training lawyers for domestic and international practice. Another important aim was to improve the administration of justice by increasing the number of lawyers who would serve rural areas. Many of these new law schools adopted clinical legal education programmes. Their clinics were styled as US-based clinics with the aim of offering real-client services.

Contributors noted however that the context of legal education was very different from that of the US. They identified concerns in Japan such as the optional status and limited credits provided to clinic courses, lack of a student practice rule especially in criminal cases, clinical teachers being appointed as adjunct professors with insufficient salaries, and greater emphasis on the simulation method and clinics than on real-client clinics. Unfortunately, scholarship over the past few years has also identified similar concerns. Law clinics in Japan are being seen as unable to provide law students enrolled in the two-year graduate programme in-depth live-client experience due to other course requirements dominating a student's time. ${ }^{40}$

A prime concern noted by the contributors was that of the low bar exam passage rate in Japan. The low bar passage rate was being linked to students not being testready for the bar exam. This in turn was being linked to the possibility that students

\footnotetext{
38 Ji Weidong, 'Legal Education in China: Reforms and Requirements' (2016) 3(2) Asian Journal of Law and Society 237, 242; Xiaobing Liu, 'Clinical Legal Education in China and the Issue of Locus Standi in Criminal Defense' (2015) 23(1) Willamette Journal of International Law and Dispute Resolution 93, 94; Wenhua Shan, 'Legal Education in China: The New "Outstanding Legal Personnel Education Scheme” and Its Implications' (2013) 13(1) Legal Information Management 10, 16.

39 Ji, 'Legal Education in China' (n 38) 242; Liu, 'Clinical Legal Education in China' (n 38) 94; Shan, 'Legal Education in China' (n 38) 16.

40 Dan Rosen, 'Japan's Law School System: The Sorrow and the Pity' (2017) 66(2) Journal of Legal Education 267, 274, 285; Leo P Martinez, 'Legal Education in a Modern World: Evolution at Work' (2015) 9(2) Charleston Law Review 267, 299.
} 
would not prefer to invest time in clinic courses that would not prepare them for bar-tested subjects. A similar concern was raised in the US as well. For instance, in 2015, an American scholar broadly hinted at this phenomenon by noting that licensing and bar admission rules do affect the law school curriculum. ${ }^{41}$ Other scholars in the US, through an empirical study of two US law schools, showed that the number of experiential courses taken by a student did not correlate with bar passage, positively or negatively. ${ }^{42}$ Undertaking a similar empirical study in Japan would be worthwhile and help address this prime concern.

\subsection{Beyond legal imperialism}

Part I of the book concluded with an exploration of whether the export of clinical legal education from the US with the support of US-based funders to other parts of the world could be legitimately described as imperialistic. Richard J Wilson opined that legal imperialism is something that is accomplished by force and exploitation, and entails an intentional and complete takeover of a legal system by a foreign power. He rejected critiques by scholars including James Gardner who argued that the export of legal education from the US was a form of American legal imperialism. He did agree with the view of Philip Genty, according to whom US models of clinical education have been oversold and at times have ignored cultural differences between civil and common law systems. However, in Wilson's view, the export of US-style clinical legal education is not and never has been a form of legal or clinical or American imperialism. Wilson based his claim on the fact that such exportation or US-based funding assistance was not in any way conquest-driven or nation-altering. Further, many clinics in the Global South have roots in their own indigenous and traditional developments, and later have come to be supported by outside funding.

In 2018, a former co-editor-in-chief of the Clinical Law Review noted that this issue of legal imperialism has remained a point of discussion at international law conferences between Global North and South clinical teachers. ${ }^{43}$ It would be worthwhile to build on existing scholarship, and explore recent scholarship to assess how clinicians have been addressing this critique of legal or American clinical imperialism. It would also be interesting to see if US clinicians and US-based clinic donors have actively engaged in addressing this critique of legal imperialism through the way they collaborate and support clinicians in the Global South.

\footnotetext{
41 Martinez, 'Legal Education in a Modern World' (n 40) 302.

42 See Robert R Kuehn and David R Moss, 'A Study of the Relationship between Law School Coursework and Bar Exam Outcomes' (2019) 68(3) Journal of Legal Education 624.

43 Richard A Boswell, review of The Global Evolution of Clinical Legal Education: More Than a Method (2018) 67(4) Journal of Legal Education 1081, 1086; see Daniel Bonilla, 'Legal Clinics in the Global North and South: Between Equality and Subordination — An Essay' (2013) 16(1) Yale Human Rights and Development Law Journal.
} 


\section{The social justice mission}

In Part II of the book, 'The Social Justice Mission', contributors provided insights into how clinics adopted different approaches to achieve locally relevant social justice missions. They provided insights into how access to justice and public interest law approaches helped meet the legal aid needs of societies. They explored how justice education approaches enabled law students to develop professional and legal ethical sensibilities. They showcased the role that community law clinics, Street Law programmes, legal literacy programmes, and Alternative Dispute Resolution clinics could play in advancing the social justice mission of legal education. Frank S Bloch viewed these insights by the contributors as a demonstration of how clinical legal education has transcended borders, and how clinics had begun to engage in a global social justice practice.

\subsection{Access to justice and legal aid}

Frank S Bloch and Mary Anne Noone examined the transformative potential and impact of legal aid clinics on clinical legal education. They noted that these clinics began as part of the access to justice movement to address systemic inequality before the law. Access to justice was a shared concern of the legal profession and the legal academy in countries including India, South Africa, the US, and Australia. They looked at three models of legal aid clinics: the 'individual service' model that caters to the needs of as many individuals as possible; the 'specialisation' model that provides legal services in a particular area of law only; and the 'community' model that is oriented to the needs of a local community and involves community organising and legal education. They examined tensions between the goals of service to clients and education to students and how one can balance these goals through the three models of legal aid clinics. Their examination highlighted two impactful results of legal aid clinics: meeting the unmet legal needs of marginalised groups, and helping students experience 'justice' in action and cultivate a professional ethic to serve the legal needs of the marginalised. These legal needs remain true even today in many countries and there is merit in strengthening existing legal aid clinics and establishing new ones to achieve these two impactful results. ${ }^{44}$

\footnotetext{
${ }^{44}$ See, e.g., Serhii Kivalov, 'Legal Clinics as an Important Element of Human Right for Free Legal Aid' (2019) 8 Ius Humani: Revista de Derecho 169; Zvonimir Jelinic, 'Legal Clinics and Access to Justice in Croatia: Perspectives and Challenges' (2018) 5(1) Asian Journal of Legal Education 99; David W Tushaus et al., 'India Legal Aid Clinics: Creating Service Learning Research Projects to Study Social Justice' (2015) 2(2) Asian Journal of Legal Education 100, 103; Arpita Sengupta and Devrupa Rakshit, 'Modernization of Legal Education in India: The Interdisciplinary Approach to Education' (2015) 2(1) Asian Journal of Legal Education 57, 65-66; Richard Grimes, 'Accessing Justice: The Role of Law School Legal Clinics in Conflict-Affected Societies' (2014) 1(2) Asian Journal of Legal Education 71; BB Pande, 'Moral and Ethical Issues Confronting Students' Legal Aid Clinics in the Outreach of Legal Services to the Resources-less and the Poor' (2013) 1 Journal of National Law University Delhi 33.
} 


\subsection{Public interest law}

Daniela Ikawa, through the examples of a legal clinic in Brazil and a clinic in Poland, highlighted public interest law's connection with reality and material justice. She argued that this connection made public interest law an effective partner for clinical legal education. Public interest law perspectives helped these clinics in bridging the gap between law and reality and in achieving material justice. She argued that public interest law perspectives took a more holistic approach as they analysed issues through a legal and socio-political lens while calling for reforms. She emphasised that teaching public interest law fostered a set of values that called for equal implementation of rights for all groups, empowered and disempowered, and that guided legal interpretation and grounded legal reform and social change work in reality. For instance, by grounding legal reform work in the context of additional barriers that certain groups faced in having their rights implemented and thus focusing on the rights of these groups.

Public interest law perspectives even today continue to be compatible partners for clinical legal education, and there is merit in expanding and supporting clinics that adopt public interest law approaches.

\subsection{Justice education for law reform}

Les McCrimmon and Edward Santow distinguished justice education from conventional legal education and saw justice education as a means to help students differentiate between law and justice and develop a commitment to justice instead of law that might be unjust. Justice education was seen to work at two levels, one where it enabled individual students to cultivate the practice of acting ethically, and the other where it enabled students to develop a broader commitment to justice. This broader commitment to justice culminated in legal action by students for law reform and changing of unjust laws. Contributors analysed externship programmes at law reform commissions. Taking Australia's example as a promising pathway, they argued that such programmes helped students to engage in law reform work with a justice education lens. They called for building of cooperative relationships between clinical legal educators and law reform commissions.

Over the past few years, clinicians have seen merit in undertaking law reform work through their clinics. ${ }^{45}$ Policy advocacy clinics have expanded and have been seen to take on more law reform work. ${ }^{46}$ A detailed mapping of collaborations (or lack thereof) between clinics and law reform commissions will prove to be a useful exercise and help clinics identify ways of building cooperative relationships to increase the impact of their law reform work.

\footnotetext{
${ }_{45}$ See, e.g., Nicholas J Schroeck, 'A Changing Environment in China: The Ripe Opportunity for Environmental Law Clinics to Increase Public Participation and to Shape Law and Policy' (2016) 18(1) Vermont Journal of Environmental Law 1.

46 For example, Policy Advocacy Clinic, University of California, Berkeley School of Law, California; Human Rights and Gender Justice Clinic, CUNY School of Law, New York.
} 


\subsection{Ethics}

Nigel Duncan and Susan L Kay made a case for how clinics that focus on preparing students for the practice of law are better suited to be a means for students to learn their professional responsibilities as lawyers rather than learning these responsibilities through an exclusive doctrinal approach. They cited examples from the US and the UK to show how jurisdictions have different means of ethical training and testing of lawyers in the form of bar-conducted exams or through completion of apprenticeships. But they highlighted how still the focus remained on teaching ethics through doctrinal courses with no room for reflective judgement. They then moved focus to show how ethics can be taught experientially through simulation, externship, and live-client clinics and the benefits and limitations of these different ways of teaching ethics. They showcased the Legal Practice and Conduct Clinic at La Trobe University in Melbourne as a promising specialist ethics clinical course. This clinic with its central focus on ethics overcame the risk that other clinics faced of neglecting ethical issues in the daily demands of the clinic caseload. It built in time for regular team discussions, reflective journalling, and navigating ethical issues through clinic faculty supervision.

Even today, clinics are seen as valuable learning sites where students develop into ethical lawyers. ${ }^{47}$ Over the past few years, many clinics including the Columbia Human Rights Clinic, where I was enrolled as a student and later served as a LLM teaching fellow, have adopted the practice of reflective journalling and checkins with clinic supervisors when students are faced with ethical situations relating to their practice of law. A detailed inquiry is required to answer the questions of whether more specialist ethics clinics have developed over the past years, and if and how generalist clinics are incorporating ethical components into their teaching and student law practice.

\subsection{Community law clinics}

Anna Cody and Barbara Schatz, who were running community law clinics, discussed two different models of community law clinics as a means of understanding the benefits and challenges of each. One clinic was run at Columbia Law School and catered to varied communities through a law school office set-up, and another at New South Wales that, due to its funding mandate, serviced only one community and was both a teaching clinic and a community legal centre. These are helpful models to study even today as they provide fundamental guidance on pedagogy and considerations that one must take into account while setting up a community law clinic.

Contributors who were running community law clinics on these models raised important questions and issues that community law clinics in general must resolve. These include questions such as how the 'community' that the clinic intends to cater to will be defined, how the client constituency and location of the clinic will

\footnotetext{
47 See, e.g., Elizabeth Curran, 'Social Justice: Making It Come Alive and a Reality for Student, and Enabling Them to Become Engaged Future Ethical Practitioners' (2018) 27(2) Nottingham Law Journal 33.
} 
be chosen, and how the clinic will balance the goals of social justice and teaching. They also identified different approaches and the role of lawyers and students in these clinics, which could lie on a spectrum from being 'collaborative', where students drew on their own as well as their client's problem-solving ability, to 'activist', where law students played a key role in identifying and implementing strategies for building community power.

These questions around approaches of community law clinics remain relevant even today. However, inquiry into other community law clinics as they function today and the formation and adoption of newer and older models may provide us insights into future promising models and practical guidance for running community law clinics today.

\subsection{Street Law}

Richard Grimes, David McQuoid-Mason, Ed O'Brien, and Judy Zimmer examined how Street Law programmes, through which the public was made more aware of its legal rights and duties, particularly Street Law programmes in the US, the UK, and South Africa, were contributing to justice education. They shed light on the origins of the Street Law programmes in the US and how these programmes came about to support the civil rights and women's rights movements. Activists had realised that in order to exercise and have one's constitutional rights implemented, one first had to really know these rights to be able to claim them. Thus, the essence of Street Law became community-based legal education in a manner that non-lawyers understood it and could use it in their everyday lives 'on the street'.

Street Law clinics enabled law schools to connect with wider communities and provided students the opportunity to develop legal skills of research, problem-solving, communication, drafting, and professional ethical law practice. These clinics differed from most other clinics to the extent that their focus was on raising community legal literacy rather than providing legal services to resolve individual legal problems. For example, in South Africa, when the country was moving away from the traditions of the apartheid era, Street Law programmes helped improve levels of literacy and became a power tool for social change. It helped the public become aware of its civic rights and encouraged it to participate in the democratic process.

Contributors argued that, while there may be many models of Street Law clinics such as the non-clinical pro bono model and the law student organisation-driven model, the credit-bearing integrated model is the most promising one. The reason is that such a model is more structured and reflective both in terms of achieving the learning goals of students and delivering outcomes to the community. The contributors listed 'best practice' points for a successful Street Law clinic that included focus on the quality of instruction by law students rather than on the quantity of classes students taught to the community, using existing relevant legal literacy materials rather than reinventing the wheel, preparing students to teach through mock peer teaching, using interactive techniques to keep the community engaged, carving time 
out for students to reflect through journalling and debriefing exercises, and ensuring that students received commensurate credit for the time they invested.

Contributors noted that integrated credit-based Street Law programmes hold untapped potential especially in developing countries including South Africa, and they can help students experience social justice while serving the society. Scholars over the past few years have observed Street Law clinics as the 'fastest-growing' and 'most popular type of legal clinic in the world'. ${ }^{48}$ Clinicians in the US have collaborated with those in Ireland and Scotland to conduct Street Law training for law students and faculty who wish to run Street Law clinics, and have identified an increased need of such training given its popularity and effectiveness. ${ }^{49}$ Other scholars have explored its potential to transcend the classroom to advance social justice in a wider societal context. ${ }^{50}$ For instance, a case has been made for the potential benefit of Street Law clinical programmes in Pakistan and India to prevent and address child sexual abuse. ${ }^{51}$

An inquiry into the multiplication of Street Law clinics and a practical mapping exercise of such Street Law clinics with the 'best practice' list-points laid out by the contributors of this book would help identify the effectiveness and integration of these clinics in the law school curriculum.

\subsection{Legal literacy programmes}

Similar to Street Law programmes, legal literacy projects have gained prominence in India. Ajay Pandey and Sheena Shukkur identified them as a means to achieve effective implementation of laws. They saw legal literacy programmes as a vehicle to bring law to reality for the disenfranchised and to help law students realise their moral responsibility as lawyers. The focus of legal literacy programmes was empowerment of citizens, especially the poor for whom implementation of their rights to food, education, and wages was fundamental for them to be able to live a dignified life. Empowerment meant educating communities about their rights and how they could exercise those rights.

By way of a case study of the Institute of Rural Research and Development's (IRRAD) Good Governance Project in Mewat village in Haryana, contributors demonstrated important links between legal literacy empowerment efforts and good rural governance. ${ }^{52}$ They demonstrated how clinical methodologies used in the IRRAD

\footnotetext{
48 Sean Arthurs et al., 'From Zero to 60: Building Belief, Capacity and Community in Street Law Instructors in One Weekend' (2017) 24 International Journal of Clinical Legal Education 118, 119.

49 Ibid. 120-121.

50 See, e.g., Cosmos Nike Nwedu, 'Taking Clinical Legal Education from Classrooms to Streets: A Practical Perspective to Solving Social Problems' (2018) 5(2) Asian Journal of Legal Education 137; Muhammad Imran Ali, 'The Role of Street Law in Preventing Child Sexual Abuse in Indo-Pak-Lessons from South Africa' (2019) 9(1) Nirma University Law Journal 119.

51 Ali, 'The Role of Street Law in Preventing Child Sexual Abuse' (n 50) 121.

52 The IRRAD's Good Governance Project was a project housed out of Sehgal Foundation. The IRRAD no longer exists as a separate entity. See Sehgal Foundation's website for more information. https://www. smsfoundation.org/good-rural-governance. Accessed 20 December 2020.
} 
project made it suitable to be run as a law school based clinic. This year-long project adopted a clinical methodology of 'learning by doing' where participating villagers and citizens applied their learning and information received in the classroom to real-life situations that they and their fellow villagers faced. The project was client-oriented and focused on the needs and legal entitlements of villagers such as their rights to food, education, health, and social security. It showcased how ordinary citizens could participate in the implementation of their legal rights through forums such as the consumer protection courts and by using tools under the Right to Information Act that welcomed participation from non-lawyers. This was an important feature as it overcame the problems posed by the legal regulatory framework in India that prohibited full-time law teachers from practising law, 'a major hurdle in developing effective clinical legal education' in India. It provided a clinical model where law teachers and students could engage in implementation of legal rights through citizen participation without violating regulatory norms. ${ }^{53}$

The clinical programme at the Jindal Global Law School (JGLS) was seen as an ally sharing a common goal with IRRAD's good rural governance goals in villages in Haryana. Contributors hoped that legal clinics would be developed in different parts of India based on the IRRAD project. They called on the Bar Council of India to help make legal education more socially relevant by supporting the integration of 'socially responsive clinical programmes' into the law school curriculum. Adopting the IRRAD project model, in 2012, a semester-long credit-based clinic course was offered at JGLS in the form of the Good Rural Governance Clinic in collaboration with Cornell Law School's International Human Rights Clinic. ${ }^{54}$ The students of this clinic, including myself at the time, had the opportunity of presenting the IRRAD project model adopted by JGLS at other law universities in India. Today, a further inquiry is required to assess the growth of legal literacy programmes and clinics in India and other countries where legal literacy is lacking.

\subsection{Alternative dispute resolution}

Karen Tokarz and V Nagaraj noted how Alternative Dispute Resolution (ADR) was emerging as a popular mode of legal practice across the world due to challenges that adversarial legal processes posed. They found ADR appealing because it was costeffective, accessible, flexible, situational, voluntary, and consensus-driven. Due to these reasons, ADR expertise was increasingly being seen as a crucial tool for social justice advocates.

With the advent of modern litigation, Indian and South African social justice advocates were noticed to be struggling to cling onto their ADR roots. Law teachers and clinicians in these countries recognising the benefits of ADR were seen to be

\footnotetext{
53 See Ajay Pandey, 'Experimenting with Clinical Legal Education to Address the Disconnect between the Larger Promise of Law and Its Grassroots Reality in India' (2011) 26 Maryland Journal of International Law 135, 143-145.

54 Kalantry, 'Promoting Clinical Legal Education and Democracy in India' (n 25) 9-11. See, generally, Gupta et al., 'How Clinical Education Builds Bridges with Villages' (n 29).
} 
strategising about how to prepare law graduates to take on the professional role of 'conflict resolvers'. One such recent pioneering clinical programme is Jindal Global University's Youth Conflict Management initiative (YCM). ${ }^{55}$ This intitiave focuses on empowering law students with skills of conflict management and dispute prevention and resolution. Law students and youth from local communities around the university are being trained as youth conflict managers and mediators. Such trained youth will soon run a clinic and provide pro bono ADR services to youth and local communities.

In relation to India, contributors also showcased the growth of ADR clinical programmes in Indian law schools fuelled by the lok adalat movement where, under the Legal Services Authorities Act 1994, law schools and their students are authorised to organise lok adalats (people's courts). They noted that most law schools in India have established legal aid cells and some cells assist individuals in the informal mediation of disputes. In relation to South Africa, contributors noted that the law school ADR curriculum was developing slowly. In relation to the US, they noted that while some ADR clinics existed, there was an urgent need for lawyers to evolve into 'conflict resolvers' rather than pursuing their traditional role of modern adversarial litigators.

Contributors acknowledged the limitations and lack of empirical data to prove the long-reaching social justice impact of ADR and left this for a future inquiry. They also acknowledged concerns that ADR-driven justice may be seen as a lesser form of justice for the poor, particularly women disputants in domestic violence cases. An inquiry into both these aspects at the present time can help make a case for the expansion of ADR clinics.

\subsection{Global relevance of clinics}

Frank S Bloch noted that clinics had gained global relevance through the rise of a global clinical community. The social justice mission of clinics had transcended borders and clinics had begun to engage in a global social justice practice. He noted some examples of this global dimension of social justice clinics. These examples included Street Law clinics in the US and South Africa, and immigration clinics in different countries that had been sustaining themselves because of the global clinical community.

Today, clinics have further transcended traditional notions of social justice and expanded beyond generalised legal aid for the poor into newer specialised categories. ${ }^{56}$ Now, they include specialised clinics - tax clinics, technology clinics, mediation clinics, entrepreneurship clinics, etc. - that tend to pay attention to the transactional and corporate side of law and cater to the needs of small business owners

\footnotetext{
55 See the Youth Conflict Management Initiative (YCM) website for more information. https://www. ycmindia.org/. Accessed 20 December 2020.

56 Kuehn, 'Surveying Clinical Education' (n 18).
} 
and taxpayers. ${ }^{57}$ These newer clinics have moved clinical legal education towards a set of students who do not see themselves as litigators. ${ }^{58}$ They are focused on training students interested in corporate and other law practices and on improving communities. The last couple of decades have also seen a rise in specialised social justice clinics such as reproductive justice clinics and gender justice clinics, and so on. For instance, CUNY School of Law's Human Rights and Gender Justice Clinic, NYU's Reproductive Justice Clinic and Columbia's Community Advocacy Lab Clinic.

The global relevance of clinics will increase as the world faces a pandemic, marginalised communities struggle to access legal services, and law schools cope with their duty of providing social justice education. These unprecedented times call for collaborations between clinics within countries and across borders to help marginalised communities access legal services. I will discuss more of these issues later on in Section 4.

\section{The global clinical movement}

In Part III of the book, 'The Global Clinical Movement and Educating Lawyers for Social Justice', clinical legal educators through their scholarship demonstrated that a global clinical movement, with the goal of social justice education through clinical legal education, was already under way. They provided insights into the defining features of clinics around the world and the global agenda of the clinical movement. They provided insights into shared concerns of clinical legal educators across borders and the support provided by international and regional clinical organisations to help address these concerns through a global clinical movement.

\subsection{Defining features of clinical legal education}

Frank S Bloch and NR Madhava Menon provided insights into how shared concerns of clinical teachers across borders regarding professional legal education, its lack of social relevance, and indifference to the unmet legal needs of the marginalised led to the development of a global network of clinical teachers and emergence of a global clinical movement. They listed three defining qualities of clinics of this movement: providing professional skills training and instilling professional values of social responsibility, using clinical methodology, and reforming legal education into social justice education. These three qualities became defining qualities of clinics worldwide and led to the building of a global clinical movement with shared goals and concerns.

Clinicians all over the world wanted to train students for the ethical practice of law oriented towards social justice. While they adopted different means to do so,

\footnotetext{
58 Ibid.

57 Ibid.
} 
they continued to share the same goal of reforming legal education. Contributors noted that a global clinical movement could offer global perspectives to benefit clinical legal education's reform agenda. Such a global movement could help take legal education beyond the cognitive level to the emotional level to question and shape social justice attitudes and ethics.

Contributors acknowledged that the global clinical movement had taken a bottom-up approach. They envisaged its further growth from the richness found in local clinical programmes. They concluded this section noting that the global clinical movement was a work in progress and, going forward, the challenge for the global movement was to:

establish itself as an effective vehicle for stimulating new ideas and encouraging new ways of thinking about clinical legal education that can arise only in a global context.... [and to understand] how clinically trained lawyers can address social justice at home and around the world.... The aim of the global movement is to develop and support clinical legal education for the benefit of legal institutions and the societies they serve - everywhere in the world. ${ }^{59}$

Over the past years, the global relevance of the clinical movement has become more prevalent with countries and regions facing shared crises. For instance, in Germany, in the context of the European refugee crisis, specialised law clinics came to be established to offer legal services to refugees. ${ }^{60}$ A present-day inquiry into and mapping of whether clinics have begun to address legal education and social justice concerns associated with the global pandemic not only in their home countries but also other countries could help in fighting this pandemic through the joint efforts of clinicians worldwide. ${ }^{61}$

\subsection{Agenda setting}

Margaret Maisel acknowledged the strides made by the global clinical movement since its crystallisation in 1999 at GAJE's first meeting in India. However, she also recognised the lack of a clear vision and a corresponding agenda of the global clinical movement as reasons for the unstructured and slow growth of the movement. She described the agenda as aimed at achieving three goals: providing greater access to justice, reforming legal education into social justice education, and creating skilled professional lawyers. She charted strategies to achieve this threefold agenda.

In relation to the goal of increasing access to justice, Maisel recommended that clinics should work in collaboration with government legal aid schemes, combine resources, and avoid duplication of efforts; advocate for developing student and

\footnotetext{
61 See, e.g., Panarairat Srichaiyarat and Ploykwan Lao-Amata, 'Legal Education during COVID-19 Pandemic: An Experience of a Thai Law School' (2020) 7(2) Asian Journal of Legal Education 228.

60 Hannemann and Dietlein, 'The Development of Refugee Law Clinics in Germany' (n 35) 165.

59 Frank S Bloch and NR Madhava Menon, 'The Global Clinical Movement' in Frank S Bloch (ed), The Global Clinical Movement: Educating Lawyers for Social Justice (Oxford University Press 2011) 277.
} 
non-lawyer practice rules in social justice cases; and equip marginalised citizens with legal knowledge and skills through Street Law-type programmes.

In relation to reforming legal education into social justice education, Maisel recommended the institutionalisation of clinical legal education in the nationally mandated law school curriculum; developing best practices for clinical legal education in each country; and training and hiring permanent clinical law faculty. Clinicians and scholars have reaffirmed this agenda goal time and again. Recently, a scholar reaffirmed this point by noting that for a law school to meaningfully achieve its objective of preparing practice-ready lawyers, it requires both integration of clinics into the mainstream curriculum as well as tenured faculty that teaches skills-based courses. ${ }^{62}$ Since the publication of the book and these recommendations, Australia has developed a best practices manual on clinical legal education that was unanimously endorsed by the Council of Law Deans in November 2012. ${ }^{63}$ Further research and inquiry are required to assess which other countries have developed a best practices manual and what support other countries require in developing such manuals.

In relation to creating skilled professional lawyers, Maisel recommended training a diverse professionally ethical student body through clinical programmes; extending support through programmes to recent law graduates in serving social needs, especially those going on to solo or small law firm practice; and working with licensing authorities to develop alternatives to bar admission exams and better programmes to help graduates develop professional skills for ethical law practice.

This threefold agenda of providing greater access to justice, reforming legal education into social justice education, and creating skilled professional lawyers remains at the forefront of the movement even today. But further collaboration and joint inquiry are required to assess to what extent these goals have been met. The contributor herself at the time had called for the development of assessment tools to map the impact of clinical legal education. She called for the establishment of a more formal structure within GAJE for implementation and assessment of this agenda. She suggested that clinicians at a country level should reach a consensus on what shall be on the global agenda based on their national needs, and then meet at an international conference to discuss ideas and map strategies for a global agenda. Since the publication of this book in 2011, clinicians have met four times at GAJE's international conferences in India, Turkey, Mexico, and Indonesia. This has given clinicians from all over the world opportunities to collaborate and map future strategies together. However, even today there isn't a formal structure within GAJE for implementation and assessment of the global agenda.

\footnotetext{
${ }^{63}$ Adrian Evans, 'Best Practices: Australian Clinical Legal Education' (2013) 47(3) The Law Teacher $421,422$.

${ }^{62}$ Rachel Arnow-Richman, 'Integrated Learning, Integrated Faculty' (2020) 92(4) Temple Law Review $745,746-748$.
} 


\subsection{Self-assessment in justice education}

Adrian Evans recognised the merit in assessing the ongoing impact of the justice education mission and found assessment indicators to be helpful in identifying areas of improvement in the movement. He developed four preliminary assessment appendixes with criteria to assess the adequacy of teaching of legal ethics, clinical programmes, staff selection, and overall law school performance. He called for law schools to publish the results of their self-assessments that could lead to setting a threshold score considered to be a passing score for clinics generally.

There have been some recent efforts to assess the teaching-service impact of clinics. ${ }^{64}$ But a closer look into the use of assessment appendixes in the book under review, and the development of new assessment methods over the past years, will help shed light on how clinicians are measuring their impact and how we can collate such information to make a case for expanding the global clinical movement.

\subsection{Clinical organisations and GAJE}

Contributors recommended that factors such as communication across borders and GAJE conferences should be tapped into more as resources to continue strengthening the global clinical movement. Margaret Martin Barry, Filip Czernicki, Izabela Kraśnicka, and Mao Ling emphasised the role that national and regional organisations from different continents have played in enabling clinical legal education to advance as a global movement. These organisations, especially GAJE, have facilitated conferences, workshops, and seminars and cross-learning forums to help clinicians across borders collaborate with and support each other. While Edward Santow and George Mukundi Wachira documented GAJE conferences up to the year 2008, it is important to document GAJE and other regional initiatives, projects, and conferences from 2011 till date. Such documentation along with an analysis of outcomes can help clinicians and other stakeholders of clinical legal education keep on their radar challenges and successes shared at the conferences and plan for future actions including projects and initiatives to address these challenges.

\subsection{Bridging different interests}

Jeff Giddings and Jennifer Lyman noted the unique role that clinical legal education played in linking five key social justice education actors and elements - clinics, clinicians, clinical pedagogies, social justice values, and students. Each of these actors and elements continues to influence legal education. Their observations are highly relevant even today and serve as a reminder of our different roles in this global clinical movement.

\footnotetext{
${ }^{64}$ See, e.g., Colleen F Shanahan et al., 'Measuring Law School Clinics' (2018) 92(3) Tulane Law Review 547.
} 
Contributors saw clinics as being well placed to teach students social justice lawyering through live-client and ethical practice. However, they acknowledged barriers to doing so, such as higher costs associated with supervision needed in clinics, lack of practice experience in academic faculty, institutional anxiety of law schools of possibly losing scholarly status, and lack of institutional integration into the law school curriculum. These issues needed to be addressed to amplify the impact of clinics on legal education and to materialise their mission of social justice education.

The contributors recognised that well-established legal educators transitioning into the role of clinical teachers were better positioned to influence the legal academy's perspectives on experiential social justice education. Clinical teachers coming from law practice were likely to spend more time in influencing the legal academy. They recommended building of a faculty culture that supports collaborations between doctrinally focused and clinical faculty as a means of introducing clinical teaching methods in doctrinal courses and training doctrinal teachers to take shared responsibilities in clinics. Simulations were observed as a clinical teaching technique that had gained recognition in mainstream legal education. However, doctrinal teachers remained resistant to other clinical teaching techniques such as live-client interaction. The reason is the 'unscripted quality' of interactive teaching methods where the teacher may lose control over their previously determined means of achieving teaching objectives.

Contributors noted student volunteer work and enthusiasm to be universally at the forefront as a driver of clinical legal and social justice education. Alumni experiences of clinical legal education were seen as strong evidence to influence the decisions of mainstream legal educators to incorporate clinics in the law school curriculum.

\subsection{Externships}

Liz Ryan Cole recognised externships as having advanced, and having great potential to advance, the global clinical movement and its social justice mission. She saw externships as a type of credit-based apprenticeship through which law students apprentice with and assist lawyers and practitioners with their legal work. She noted that externships were a popular model all over the world, and had three essential components: the student's experience of the law in a professional setting, the student's reflection and learning guided by an externship supervisor, and law school support for such student externship in the form of academic credit for such learning. In 2017, scholars noted a growth of externship programmes in Australia. ${ }^{65}$ It might be worthwhile to inquire into the blooming of externship programmes in other countries in contrast to expansion of law school based clinics. Externships might provide a cost-effective alternative for providing skills training to law students.

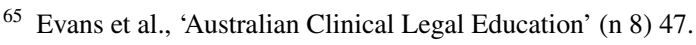




\subsection{Scholarship}

Neil Gold and Philip Plowden noted how clinical scholarship is different from traditional legal scholarship. Students, supervising lawyers, and law professors often undertake clinical scholarship. It was often seen to be observational and empirical, and focused on professional skills training, social justice, and experiential learning. While it was seen to have grown exponentially between the 1970s and early 2000s, contributors identified a need for clinical scholarship to be more global in its sensitivity. They called for clinical scholarship to adopt a framework that allows for wider lessons to be learnt by clinics across borders in order to effectively advance 'global justice'. Such scholarship can address the concern of developing effective clinical pedagogy and advancing the justice education concerns of clinicians all over the world. Thus, scholarship needs to be reflective of the social justice mission of the global clinical movement.

In 2018, Richard Boswell, former coeditor-in-chief of the Clinical Law Review, noted that clinical legal scholarship over the years had become more global in nature. ${ }^{66}$ The Clinical Law Review's 25th anniversary issue in 2019 is a valuable effort in this direction. ${ }^{67}$ It inventories books and journals from around the globe on clinical legal education, and emphasises the need for international scholarship and support for clinical writing. ${ }^{68}$ One of the articles in this issue provides insights into the relationship of a noted clinician with her scholarship. She describes her relationship to written scholarship as 'on-again, off-again' and her path to becoming a 'clinician-scholar'. ${ }^{69}$ Such candid scholarship can inspire many clinicians as they navigate and build their own written scholarship.

While providing inspiration, another article in the Clinical Law Review notes the drop in financial resources at law schools due to lower student enrolment rates and the contemporary challenge in the US of inadequate support for clinics and clinical scholarship. ${ }^{70}$ The same threat is conceivable today for law schools in other parts of the world that are under-resourced and might be facing additional financial burdens due to the economic downturn triggered by the COVID-19 pandemic, and where traditional legal scholarship is anyway prioritised over clinical scholarship.

\footnotetext{
70 Peter A Joy, 'Challenges to Legal Education, Clinical Legal Education, and Clinical Scholarship' (2019) 26(1) Clinical Law Review 237, 261-262.

69 Binny Miller, 'Accidental Scholar: Navigating Academia as a Clinician and Reflecting on Intergenerational Change' (2019) 26(1) Clinical Law Review 329, 330.

68 Ibid.

67 Leah Wortham, 'Strengthening the International Clinical Scholarly Community: Opportunities for the Clinical Law Review and Beyond' (2019) 26(1) Clinical Law Review 393, 394.

66 Boswell, review of The Global Evolution of Clinical Legal Education (n 43) 1085.
} 


\section{The COVID-19 pandemic}

While the pandemic has created challenges for legal educators generally, it has specific consequences for clinical legal educators who adopt the pedagogy of learning by doing. With law schools resorting to remote online teaching, clinical educators will have to develop innovative methods of providing experiential learning to law students. Clinical educators at Columbia's Human Rights Clinic have adopted a hybrid approach where some classes are being taught online and some in person with complete adherence to social distancing and other health safety norms. The Association of American Law Schools has organised information and resources relating to legal education to help law faculty plan for classes during this pandemic. ${ }^{71}$ This includes tips and materials to help law faculty plan for teaching hybrid and online classes and questionnaires to assess the impact of the pandemic and shelter-in-place policies on legal education, including on the continuation of experiential learning courses. ${ }^{72}$ Law school regulatory agencies and relevant associations in other countries should also consider undertaking such an exercise to support social justice education during this pandemic.

In an increasingly virtual world, with court hearings, client meetings, and other matters happening over video conferencing, student clinical experiences where possible may well transform into virtual experiential learning and become the new normal. The problem might be particularly acute for clinical educators in developing and least developed countries where internet, WhatsApp, and other communication and technology tools may not be as easily accessible to communities. This can be used as an opportunity for clinical educators, clinic students, and their partnering communities to engage in collaborative problem solving.

Some scholarship has begun to emerge on how the pandemic is affecting legal education in Thailand, and there is also some scholarship providing a general analysis of how the pandemic might be affecting law clinics in India. ${ }^{73}$ However, a specific inquiry into how the pandemic is particularly impacting clinical legal education in different parts of the world is required, and the global clinical community needs to collaborate to overcome the challenges of providing practical legal training to law students in today's increasingly virtual world. The next GAJE conference may well be organised virtually, and imparting clinical legal education in the pandemic can be its core theme. Through thought leadership and collaboration, innovative

\footnotetext{
73 See, e.g., Srichaiyarat and Lao-Amata, 'Legal Education during COVID-19 Pandemic' (n 61); Vijendra Kumar, 'Clinical Legal Education during Covid-19 Pandemic: Issues and Perspectives' (2020) ILI Law Review (Special Issue) 241; Susmitha P Mallaya, 'Contouring Legal Education in India: An Analysis of Challenges Posed by COVID-19' (2020) ILI Law Review (Special Issue) 147.

72 See Jessica Erickson, 'Designing an Inclusive \& Supportive Classroom Environment - Preparing for Fall Teaching in Physically Distanced, Hybrid, or Remote Courses' (PrawfsBlawg, 21 August 2020). Available at AALS, 'Legal Education in the Time of COVID-19' (n 71). See also American Bar Association, 'ABA Releases 9-Part Questionnaire on Law School Responses to COVID-19 in Spring 2020'. Available at AALS, 'Legal Education in the Time of COVID-19' (n 71).

71 See Association of American Law Schools (AALS), 'Legal Education in the Time of COVID-19'. https://www.aals.org/covid19/. Accessed 20 December 2020.
} 
clinical teaching methods suitable to the current pandemic environment need to be developed.

\section{Conclusion}

The Global Clinical Movement is a book that undertook the rigorous task of setting the stage for advancing the global clinical movement at a time when it was seen to be under way. Almost a decade has passed since the publication of this book. I suggest the publication of a revised edition of this book in an effort to continue moving the global clinical movement forward. The revised book should map in detail the growth of the clinical movement over the past decade and analyse contemporary challenges including those identified in this book review. It should aim to lay out a concrete agenda and strategies for its growth over the next decade. In Sections 1-3 of this book review, I have identified contemporary challenges and other areas warranting further inquiry. These can serve as starting points for scholars who wish to take up this project of laying out a renewed agenda for the global clinical movement informed by contemporary issues. I wish to re-emphasise some of these issues warranting detailed inquiry that can benefit from the collaborative thought leadership of clinicians. It would be crucial for these issues to feature in the revised edition of this book. Scholarship and inquiry into these issues will help build the global clinical movement and develop an effective response to challenges that the movement is facing today.

\subsection{Pandemic-focused scholarship and studies}

Over the past years, the global relevance of the clinical movement has become more prevalent with countries and regions facing shared crises. For instance, in Germany, in the context of the European refugee crisis, specialised law clinics came to be established to offer legal services to refugees. ${ }^{74}$ A present-day inquiry and mapping of whether clinics have begun to address legal education and social justice concerns associated with the global pandemic not only in their home country but also other countries could help in fighting the pandemic through the joint efforts of clinicians worldwide. $^{75}$

Today, it is imperative to undertake inquiry and scholarship to respond to the impacts of the pandemic on clinical legal education and social justice goals. This exercise is key to planning for the present and near future of clinical legal education and keeping up the momentum of the global clinical movement. The next edition of the book shall adopt a framing that analyses challenges and opportunities for the growth of the clinical movement in the context of the current pandemic.

\footnotetext{
75 See, e.g., Srichaiyarat and Lao-Amata, 'Legal Education during COVID-19 Pandemic' (n 61).

74 Hannemann and Dietlein, 'The Development of Refugee Law Clinics in Germany' (n 35) 165.
} 


\subsection{Breaking the myths around clinical education's relation to law school tuition fees and bar exam passage rate}

Scholarship in the US has debunked the recent claim that clinics increase law school tuition fees. ${ }^{76}$ Specific studies can be undertaken in other countries where such a claim might be hindering institutional support to clinics. In another vein, in Japan, a prime concern noted by the contributors of this book was that of low bar exam passage rate. The low bar passage rate was being linked to students not being test-ready for the bar exam. A similar concern was raised in the US as well. ${ }^{77}$ Scholars in the US, through an empirical study published after this book, showed that the number of experiential courses taken by a student did not correlate with bar passage. ${ }^{78}$ Undertaking a similar empirical study in Japan would be worthwhile to help address this concern.

\subsection{Development of clinical education in African countries beyond Nigeria and South Africa}

There is a need for a systematic inquiry into the development of clinical legal education in African countries other than Nigeria and South Africa, especially those that have not been discussed at all in the book. ${ }^{79}$ Strategies need to be developed as to how the global clinical movement and clinics in Nigeria and South Africa can support local clinics in other African countries. Integrated credit-based Street Law programmes hold untapped potential especially in developing countries including South Africa and can help students experience social justice while serving the society. An inquiry into the multiplication of Street Law clinics and a practical mapping exercise of such Street Law clinics with the 'best practice' list-points laid down by the contributors of this book would help identify the effectiveness and integration of these clinics in the law school curriculum.

\subsection{Development of clinics in Europe, the Middle East, and Latin America}

Over the past few years, scholars have noted the uneven development of clinics in Central and Eastern Europe. ${ }^{80}$ This uneven development requires closer scrutiny and clinicians from the region who have been able to establish and sustain their clinic work may be well positioned to support their peers in the region. The last few years have seen emerging scholarship on clinical legal education in Western Europe and

\footnotetext{
${ }^{80}$ Aksamovic and Genty, 'An Examination of the Challenges, Successes and Setbacks' (n 30) 433-434. See Ważyńska-Finck, 'Poland as the Success Story' (n 30).

79 Osiemo and Kok, 'Promoting a Public Service Ethic in the Legal Profession in Kenya' (n 20).

78 See Kuehn and Moss, 'A Study of the Relationship between Law School Coursework and Bar Exam Outcomes' (n 42).

77 Martinez, 'Legal Education in a Modern World' (n 40) 302.

76 Kuehn, 'Pricing Clinical Legal Education' (n 16) 5.
} 
the Middle East. ${ }^{81}$ Especially because Western Europe and the Middle East were regions not covered by the book, it might be useful to delve deeper, build more scholarship, and identify areas for collaboration to support the growth of clinical legal education in Western Europe and the Middle East. While there has been some examination of the clinical education movement in Latin America, ${ }^{82}$ there is a need for more recent scholarship on how the movement has grown there.

\subsection{Specialist ethics clinics and general clinics}

Clinics have always been and continue to be valuable learning sites where students can develop into ethical lawyers. Over the past few years, many clinics including the Columbia Human Rights Clinic have adopted the practice of reflective journalling and check-ins with clinic supervisors when students are faced with ethical situations relating to their practice of law. A detailed inquiry is required to answer the questions of whether more specialist ethics clinics have developed over the past years, and if and how generalist clinics are incorporating ethical components into their teaching.

\subsection{Proving the social justice impact of ADR and mediation clinics}

There is a need to collect empirical data to prove the long-reaching social justice impact of ADR clinics and to verify claims about whether ADR and mediation processes lead to lesser justice for the poor and women disputants. This was a gap identified by the contributors of the book that does not seem to have been filled comprehensively till date. A present inquiry into both these aspects and current initiatives such as the Youth Conflict Mediation (YCM) Initiative can help make a case for the expansion of ADR and mediation clinics in a manner that addresses these critiques.

\subsection{Public interest litigation and lok adalats}

While in India public interest litigation and lok adalats are promising avenues for law clinics to engage in social justice education, there is dearth of data on how these avenues are being used by clinics. There is a need to fill this gap in data by undertaking a methodological study on this issue and encouraging clinics to tap into the opportunities of engaging in public interest litigation and lok adalats. In South and Southeast Asia, fully accredited clinical programmes still remain the exception and further movement building and scholarship are required in this region.

\footnotetext{
82 See generally Wilson, 'Clinical Legal Education in Latin America' (n 37); Munoz L, 'Cause Lawyering and Compassionate Lawyering' (n 37).

81 See Wilson, 'Clinical Legal Education in the Middle East' and 'Clinical Legal Education in Continental Western Europe' (n 33); Torabi and Noori, 'The Necessity of Transitioning from Generic Legal Clinics' (n 33); Alemanno and Khadar, Reinventing Legal Education (n 1).
} 


\subsection{Shared lessons}

It is important that clinician-scholars continue to amplify the global reach of clinical legal education through shared lessons and develop strategies informed through such shared lessons to combat the challenges posed by the pandemic and other common challenges. There is great potential to learn lessons across borders and tap into the global reach of clinics to address contemporary challenges that clinics worldwide are facing. For instance, challenges of funding, pay disparities in salaries of clinicians and professors, the mindset at some law faculties of seeing clinics as co-curricular, and restrictions on law students with regard to representing clients facing summary conviction criminal charges are common challenges. A number of countries discussed in this book seem to be grappling with similar challenges. There is an opportunity for collaboration between these countries.

It is concerning that over the past years, a new list of challenges associated with clinics has been identified in China. These challenges include the impacts of the COVID-19 pandemic, lack of funding, heavy research duties of teachers, teachers' lack of practical legal experience to be able to teach these courses, lack of stable institutional arrangements with practising lawyers to serve as teachers for these courses, and lack of locus standi for clinic students in criminal matters. ${ }^{83}$ An organised inquiry is required into how the global clinical movement and clinics in other countries can help clinicians in China address these challenges.

\subsection{GAJE and other regional initiatives}

It is important to document GAJE and other regional initiatives, projects, and conferences from the publication of the book till date. Such documentation along with an analysis of its outcomes can help clinicians and other stakeholders of clinical legal education keep on their radar the challenges and successes shared at the conferences and plan for future actions to address these challenges. The next GAJE conference can be organised virtually and it can be a forum to tackle the looming question of how clinics can continue imparting social justice education during the current pandemic. This can be its core theme.

\subsection{Where we stand with the critique of clinical imperialism}

The issue of whether the export of clinical legal education from the US to other parts of the world is an imperialistic endeavour has remained a point of discussion at international law conferences. It would be worthwhile to build on existing scholarship, and explore recent scholarship to assess how clinicians have been addressing this critique. It would also be interesting to see if US clinicians and US-based

\footnotetext{
83 Ji, 'Legal Education in China' (n 38) 242; Liu, 'Clinical Legal Education in China' (n 38) 94; Shan, 'Legal Education in China' (n 38) 16.
} 
clinic donors have actively engaged in addressing this critique of legal imperialism through the way they collaborate with and support clinicians in the Global South.

\subsection{Self-assessment of the global clinical movement}

The agenda of the global clinical movement (as documented in the book) of providing greater access to justice, reforming legal education into social justice education, and creating skilled professional lawyers remains at the forefront of the movement even today. Further collaboration and joint inquiry are required to assess to what extent these goals have been met. There have been some recent efforts to assess the teaching-service impact of clinics. ${ }^{84}$ But a closer inquiry into currently used assessment methods as well as the assessment appendixes developed by the contributors of this book may help shed light on how clinicians are measuring their impact. Such an inquiry may help in developing a method to collate such self-assessment information to make a case for expanding the global clinical movement.

\subsection{Candid scholarship on becoming a 'clinician-scholar'}

There is a need for more candid scholarship that can inspire clinicians in navigating and building their own globally relevant written scholarship. ${ }^{85}$ While providing access to inspiring scholarship, the Clinical Law Review itself in another article noted the contemporary challenge in the US of inadequate support for clinics and clinical scholarship. ${ }^{86}$ The same threat is conceivable today for law schools in other parts of the world - law schools that are under-resourced and might be facing additional financial burdens due to the economic downturn triggered by the COVID-19 pandemic, and law schools where traditional legal scholarship is anyway prioritised over clinical scholarship.

The hope is that clinician-scholars combine resources and collaboratively take up the above-identified inquiries and produce scholarship with the aim of amplifying the three key aspects of clinical legal education: its global reach, its social justice mission, and its emergence as a global clinical movement.

Publisher's Note Springer Nature remains neutral with regard to jurisdictional claims in published maps and institutional affiliations.

\footnotetext{
84 See, e.g., Shanahan et al., 'Measuring Law School Clinics' (n 64) 547.

85 Miller, 'Accidental Scholar' (n 69) 330.

86 Joy, 'Challenges to Legal Education' (n 70) 261-262.
} 